\title{
Giardia and Cryptosporidium in inflowing water and harvested shellfish in a Lagoon in Southern Italy
}

\author{
Annunziata Giangaspero a,b,*, Roberta Cirillo a ${ }^{a}$ Vita Lacasella ${ }^{c}$, Antonio Lonigro ${ }^{\mathrm{d}}$, Marianna Marangi a \\ Pasqua Cavallo ${ }^{c}$, Federica Berrilli ${ }^{\mathrm{e}}$, David Di Cave ${ }^{\mathrm{e}}$, Olga Brandonisio ${ }^{\mathrm{c}}$ \\ a Dipartimento di Scienze delle Produzioni, dell'Ingegneria e della Meccanica e dell'Economia Applicate ai Sistemi Agro-Zootecnici, University of Foggia, 71100 Foggia, Italy \\ b Centro di Ricerca Interdipartimentale BIOAGROMED, University of Foggia, 71100 Foggia, Italy \\ c Dipartimento di Clinica Medica, Immunologia e Malattie Infettive, University of Bari, 70124 Bari, Italy \\ d Dipartimento di Scienze delle Produzioni Vegetali, University of Bari, 70126 Bari, Italy \\ e Dipartimento di Sanità Pubblica e Biologia Cellulare, University of Tor Vergata, 00133 Rome, Italy
}

\section{A R T I C L E I N F O}

\section{Article history:}

Received 12 February 2008

Received in revised form 22 July 2008

Accepted 25 July 2008

Available online 7 August 2008

\section{Keywords:}

Giardia

Cryptosporidium

Water

Shellfish

Lagoon

Epidemiology

\begin{abstract}
A B S T R A C T
Giardia and Cryptosporidium spp. are important enteric protozoan pathogens for humans and animals, and have been found to contaminate water as well as edible shellfish all over the world. This is the first study to simultaneously investigate the presence of Giardia and Cryptosporidium in inflowing water and harvested shellfish in a geographically closed environment (Varano Lagoon, Southern Italy). Samples of treated wastewater were collected each month - at the outlet from the treatment plant, and downstream at the inlet into the lagoon - from the channels flowing into the Lagoon, together with specimens of Ruditapes decussatus and Mytilus galloprovincialis from shellfish-farms on the same lagoon. Giardia cysts were found by immunofluorescence (IF) microscopy in 16 out of 21 samples of treated wastewater and in 7 out of 21 samples from downstream water channels, and viable cysts were also detected by a $\beta$-giardin RT-PCR. G. duodenalis Assemblages A and B were identified by small ribosomal subunit (18S-rDNA) and triosephosphate isomerase (tpi)-PCR, followed by sequencing. Cryptosporidium oocysts were found by IF in 5 out of 21 wastewater samples, and in 8 out of 21 samples from water channels. Molecular analysis identified the zoonotic species Cryptosporidium parvum by oocyst wall protein (COWP)-PCR and sequencing. Higher concentrations of Giardia cysts than Cryptosporidium oocysts were registered in almost all wastewater and water samples. IF and molecular testing of shellfish gave negative results for both protozoa. Wastewaters carrying Giardia and Cryptosporidium (oo)cysts are discharged into the Lagoon; however, the shellfish harvested in the same environment were found to be unaffected, thus suggesting that physical, ecological and climatic conditions may prevent contamination of harvested shellfish.
\end{abstract}

(c) 2008 Published by Elsevier Ireland Ltd.

\section{Introduction}

The flagellate Giardia and the coccidian Cryptosporidium are protozoan parasites of vertebrates and well-known causative agents of gastrointestinal diseases. Cysts and oocysts excreted by infected hosts may cause human infection through ingestion of contaminated water and/or food.

Six Giardia species are recognised, but only Giardia duodenalis infects humans and a wide variety of mammals. This species has recently been considered a species complex of seven Assemblages (A-G); Assemblages A and B infect both humans and animals, while the others do not infect humans and are mainly host-specific [1,2]. At least fifteen species have been recognised in the Cryptosporidium genus, with high intraspecific phenotype and genotype variability

\footnotetext{
* Corresponding author. Facoltà di Agraria, Dipartimento PR.I.M.E., Via Napoli 25 71100 Foggia, Italy. Tel.: +39 0881 589227; fax: +39 0881740211.

E-mail address: a.giangaspero@unifg.it (A. Giangaspero).
}

[3]. The primary host of Cryptosporidium hominis is human, whereas Cryptosporidium parvum exhibits the highest zoonotic potential [4].

In Italy, (oo)cysts have been detected in river water, in watersheds and watercourses, in well water used for agricultural purposes, in swimming pools and in wastewater even after treatment [5]. Molecular typing performed in Italy on wastewater showed that isolates belonged mostly to G. duodenalis Assemblage A and C. parvum species [5].

Many vegetables irrigated with contaminated water have tested positive for Giardia and/or Cryptosporidium (oo)cysts all over the world [6], and outbreaks due to fruit and/or vegetables have been documented [7]. However, besides vegetables and fruit surfaces, fresh and marine molluscs can be a potential vehicle of transmission due to their ability to concentrate (oo)cysts from large volumes of contaminated water. Giardia and Cryptosporidium were detected in several species of edible shellfish both in the USA [8-12] and in Europe [13-16]. In Italy Giardia cysts and C. parvum oocysts have been documented in edible shellfish (Chamelea gallina), and, more recently C. parvum and C. hominis have also been detected in Manila clams (Ruditapes philippinarum) [5]. 
Although there are plentiful data available about the presence of protozoa in water and in shellfish, these data are disconnected with each other because they have been individually reported (only water or only shellfish) and/or derive from different geographical locations and time periods. In order to overcome this limitation, we investigated the presence and species/genotypes of Giardia and Cryptosporidium in a clearly-defined and distinct geographical and ecological environment (the Varano Lagoon, Apulia region, Southern Italy), into which different kinds of water are discharged, including wastewater and rainfall, and where shellfish are harvested. Therefore, the objective of this study was to carry out simultaneous analysis for the presence of Giardia and Cryptosporidium (oo)cysts on water inflowing into the Varano Lagoon and shellfish harvested in the same environment throughout a one year period. In particular, final effluents of two wastewater treatment plants were sampled monthly at two different sites: the channel outlets from the plants and the channel inlets where they flow into the Lagoon. Moreover, shellfish (Ruditapes decussatus and Mytilus galloprovincialis) harvested in the Varano Lagoon were collected each month in the same period and analyzed.

\section{Materials and methods}

\subsection{Geographical area and sampling sites}

The Varano Lagoon $\left(41^{\circ} 52^{\prime} \mathrm{N}-41^{\circ} 45^{\prime} \mathrm{E}\right)$ is located in the northern part of the Apulia region (South Italy). It has a trapezoidal shape and a surface area of about $65 \mathrm{~km}^{2}$ and communicates with the Adriatic Sea through two artificial isthmi (Foce Capoiale and Foce Varano) at the two ends of a long narrow costal dune. The water in the lagoon is $50 \mathrm{~cm}$ to $5 \mathrm{~m}$ deep. In the south-eastern part of the Varano Lagoon, two main water channels (Sant ${ }^{\prime}$ Antonino and San Francesco) drain water into the Lagoon from two municipal wastewater treatment plants (one discharges chlorinetreated wastewater, and the other discharges chlorine- plus UV-treated wastewater), as well as rainfall runoffs. Two shellfish farms ( $R$. decussatus and M. galloprovincialis) which cover a total area of $750 \times 1200 \mathrm{~m}$ are located in the north-south direction $\left(41^{\circ} 53^{\prime} \mathrm{N}-15^{\circ} 44^{\prime} \mathrm{E}\right)$ of the Varano Lagoon (Fig. 1)
Wastewater and water samples were taken from the following sites:

Site 1: Final effluent from the wastewater treatment plant - serving about 9000 inhabitants in the town of Cagnano Varano which uses the following technology: secondary treatment by activated sludge, followed by final disinfection achieved using sodium hypochlorite $\left(5 \mathrm{mg} \mathrm{L}^{-1}\right)$.

Site 2: Mouth of water channel (San Francesco) draining wastewater from the Cagnano Varano treatment plant.

Site 3: Final effluent from the wastewater treatment plant - serving about 5000 inhabitants in the town of Carpino - which uses the following technology: after secondary treatment by activated sludge and sedimentation, disinfection is performed by sodium hypochlorite $\left(3 \mathrm{mg} \mathrm{L}^{-1}\right)$, followed by disk filtration and final disinfection using low pressure and high density UV (dose $33 \mathrm{~mJ} / \mathrm{cm}^{-2}$ ) lamps (Koninklijke Philips Electronics N.V. Eindhoven, the Netherlands).

Site 4: Mouth of water channel (Sant' Antonino), draining from the Carpino wastewater treatment plant.

\subsection{Water sampling and processing}

From February 2006 to January 2007, we made monthly collections consisting of $20 \mathrm{~L}$-samples of final wastewater at the channel outlets from the two treatment plants, and 10 L-samples from the channel inlets where they flow into the Varano Lagoon. All samples were processed by the same method as previously described [17]. Briefly, samples were filtered through a yarn-wound cartridge filter (Atlas Filtri, Italy) of $1 \mu \mathrm{m}$ nominal porosity (maximal pressure 3 bar, maximal flux speed $6 \mathrm{~L} / \mathrm{min}^{-1}$ ). After filtration, the filter was removed, maintained at $+4{ }^{\circ} \mathrm{C}$ and transferred in a plastic bag containing a small amount of filtered water to the laboratory where it was processed within $48 \mathrm{~h}$ from sampling. The cartridge filter was cut into pieces and then washed in buffered detergent solution containing 0.1\% Tween$80,0.1 \%$ sodium dodecyl sulphate (SDS) and $0.005 \%$ Anti-foam B (all from Sigma) in phosphate buffered saline (PBS) pH 7.2, until complete clarification of the fibres. The fluid obtained was concentrated by
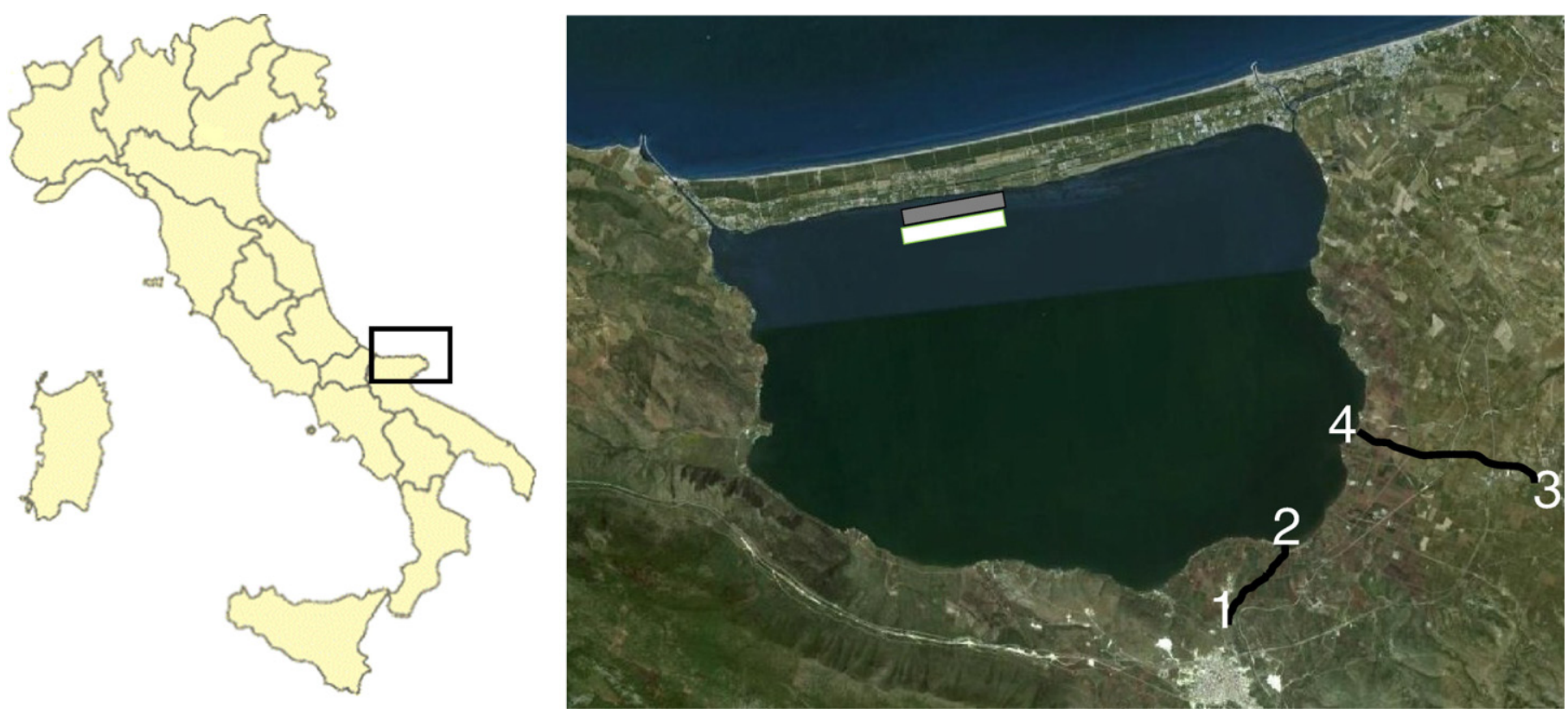

Fig. 1. Map of Italy and the Varano Lagoon (Apulia region) with shellfish farms and collection site locations. 
centrifugation at $1800 \times \mathrm{g}$ for $15 \mathrm{~min}$ at $+4{ }^{\circ} \mathrm{C}$, and the sediment was used for (oo)cyst purification from particulates and debris by Percollsucrose (sp. gr. 1.10) flotation.

\subsubsection{Direct immunofluorescence test}

The sediment obtained was applied to slides for direct immunofluorescence (IF), and stained using a commercially available kit (MERIFLUOR $^{\circledR}$ Cryptosporidium/Giardia; Meridian Diagnostic, Cincinnati, $\mathrm{OH}, \mathrm{USA}$ ), according to the manufacturer's instructions. After incubation with FITC-labelled anti-Giardia and anti-Cryptosporidium mAbs and washing, slides were further incubated for 1 min with $50 \mu \mathrm{L}$ of $4^{\prime}, 6$ diamidino-2-phenylindole (DAPI) (SIGMA D9542) stain, according to USEPA method 1623 [18]. Finally, (oo)cysts were identified and counted by fluorescence microscopy (Nikon) at $400 \times$ on the basis of apple-green fluorescence, intense blue internal staining or sky-blue nuclear staining with DAPI and internal morphology by differential interference contrast. The results were expressed as the number of (oo)cysts $\cdot \mathrm{L}^{-1}$ of the sampled water.

\subsection{2. $\beta$-giardin RT-PCR}

On samples tested positive to Giardia cysts by IF assay, a $\beta$-giardin RTPCR was used to evaluate cyst viability, according to Kaucner e Stinear [19]. RNA was extracted by the RNAzol Kit (Molecular probes), according to manufacturer instructions, dosed by a spectrophotometer and subjected to electrophoresis. After treatment with Rnase-free bovine pancreatic DNase I (Roche Corporation) for $15 \mathrm{~min}$ at room temperature to eliminate DNA contamination, followed by DNase inactivation by 2,2 mM EDTA, pH 8.0, and incubation at $65^{\circ} \mathrm{C}$ for $10 \mathrm{~min}, 3 \mu \mathrm{g}$ of RNA from both DNase-treated and untreated samples were subjected to RT-PCR in a solution $(20 \mu \mathrm{l})$ containing incubation buffer for M-MuLV reverse transcriptase $1 \times, 40 \mathrm{mU}$ primer $\mathrm{p}(\mathrm{dT})_{15}, 0.2 \mathrm{mM}$ dNTPs, $25 \mathrm{U}$ protector RNase inhibitor, $40 \mathrm{U}$ Reverse Transcriptase (M-MuLV) (all from Roche Corporation) in a thermal cycler (Perkin Elmer 2400) at $37^{\circ} \mathrm{C}$ for $60 \mathrm{~min}$. After reverse transcriptase inactivation by heating, a fragment (171 bp) of the $\beta$-giardin gene was amplified by PCR with the forward primer GGL 5'-AAGTGCGTCAACGAGCAGCT-3' and the reverse primer GGR 5'TTAGTGCTTTGTGACCATCGA-3' [20]. PCR was performed in $50 \mu \mathrm{l}$ containing PCR reaction buffer $1 \times, 0.5 \mu \mathrm{M}$ of each primer, $0.2 \mathrm{mM}$ dNTPs, $2 \mathrm{U}$ Taq DNA Polymerase (all from Roche Corporation) in the following conditions: 40 denaturation cycles at $95^{\circ} \mathrm{C}$ for $1 \mathrm{~min}$, an annealing step at $61{ }^{\circ} \mathrm{C}$ for $1 \mathrm{~min}$, an extension step at $72{ }^{\circ} \mathrm{C}$ for $1 \mathrm{~min}$ and final extension at $72{ }^{\circ} \mathrm{C}$ for $7 \mathrm{~min}$. The PCR products were separated on a 1.6\% agarose gel and UV visualized after ethidium bromide staining and then confirmed by sequencing. Negative and positive controls were included in each PCR run. Positive controls were performed by using RNA extracted from Giardia cysts and promptly subjected to reverse transcription. Giardia cysts were obtained from trophozoites $\left(\mathrm{WB}_{6} \mathrm{C}_{6}\right.$ strain, provided by Istituto Superiore di Sanità, Rome, Italy) and then cultured for encystation protocol [21,22].

\subsection{Shellfish sampling and processing}

On the basis of the following criteria: infinite population, expected prevalence $(0.14 \%)$, maximum error desired $(0.3 \%)$ and confidence level (95\%) [23], 60 shellfish were collected each month from February 2006 to January 2007 for a total of 1385 specimens of clams (665 R. decussatus) and mussels ( $720 \mathrm{M}$. galloprovincialis) harvested in the Varano Lagoon (Fig. 1). The clams were kept at $0-5{ }^{\circ} \mathrm{C}$ until they reached the laboratory, where they were measured, weighed (live weight) and pooled ( 2 pools of 30 molluscs month/site) for convenience.

\subsubsection{Haemolymph concentration}

Following the procedures previously described [24,25,41], haemolymph was aspirated from each bivalve (approximately $100 \mu \mathrm{L} / \mathrm{clam}$ ), pooled according to the site of collection and to the number of molluscs. Each pool was concentrated in a $1 \mathrm{M}$ sucrose solution and centrifuged at $400 \times \mathrm{g}$ for $15 \mathrm{~min}$. The interface was then aspirated, re-suspended in $4 \mathrm{~mL}$ of saline $(0.9 \% \mathrm{NaCl})$ and centrifuged at $600 \times \mathrm{g}$ for $10 \mathrm{~min}$. The supernatant was finally removed by aspiration, leaving $1.5 \mathrm{~mL}$ of concentrated sample volume, including the pellet. The haemolymph $(50 \mu \mathrm{l}$ from each pool) was dried on glass microscope slides and examined by fluorescence microscopy after staining with FITC-labeled antibodies as described by the manufacturer (MERIFLUOR ${ }^{\circledR}$ Cryptosporidium/Giardia; Meridian Diagnostic, Cincinnati, OH, USA).

\subsection{Molecular characterization of Giardia and Cryptosporidium (oo)cysts from water and shellfish}

Water samples which tested positive for Giardia and Cryptosporidium by IF assay and all shellfish haemolymph samples were subjected to molecular tests.

DNA was extracted using QIAamp DNA Mini Kit (Qiagen) for PCR and stored at $-20{ }^{\circ} \mathrm{C}$. Two loci were used for Giardia spp. genotyping, a fragment of about $250 \mathrm{bp}$ within the gene encoding for the triosephosphate isomerase (TPI), and a fragment of about $130 \mathrm{bp}$ within the gene encoding for the small ribosomal subunit (18S-rDNA).

Table 1

Giardia cyst and Cryptosporidium oocyst concentration detected by IF microscopy throughout the year

\begin{tabular}{|c|c|c|c|c|c|c|c|c|}
\hline \multirow{2}{*}{$\frac{\text { Sampling sites }}{\text { Months }}$} & \multicolumn{2}{|l|}{ Site 1} & \multicolumn{2}{|l|}{ Site 2} & \multicolumn{2}{|l|}{ Site 3} & \multicolumn{2}{|l|}{ Site 4} \\
\hline & Cyst $\mathrm{N} \mathrm{L}^{-1}$ & Oocyst $\mathrm{N} \mathrm{L}^{-1}$ & Cyst $\mathrm{N} \mathrm{L}^{-1}$ & Oocyst $\mathrm{N} \mathrm{L}^{-1}$ & Cyst $\mathrm{N} \mathrm{L}^{-1}$ & Oocyst $\mathrm{N} \mathrm{L}^{-1}$ & Cyst $\mathrm{N} \mathrm{L}^{-1}$ & Oocyst $\mathrm{N} \mathrm{L}^{-1}$ \\
\hline Feb. & 271.00 & 0 & $10,454.00$ & 0 & 9.00 & 0 & $\mathrm{NI}$ & $\mathrm{NI}$ \\
\hline Mar. & 29.24 & 0 & 1.44 & 3.60 & 82.67 & 0 & 0 & 0 \\
\hline Apr. & 37.00 & 0 & 1172.62 & 63.00 & $8.76^{*}$ & 0 & 0 & 0 \\
\hline May & 0 & 0 & 0 & 0 & 0 & 0 & 0 & 0 \\
\hline Jun. & 491.80 & 23.46 & 2.48 & 6.0 & 0 & 0 & 0 & 0 \\
\hline Jul. & 16.46 & 0 & 0 & 0 & 157.35 & 0 & 0 & 0 \\
\hline Sept. & 87.00 & 14.00 & 0 & 102.00 & $\mathrm{NI}$ & NI & 0 & 102.00 \\
\hline Oct. & 0 & 0 & 0 & 0 & 0 & 0 & 0 & 0 \\
\hline Nov. & 41.66 & 13.38 & 44.44 & 22.22 & 66.67 & 26.66 & 0 & 0 \\
\hline Dec. & $68.00 *$ & 25.50 & 7629.50 * & 5834.50 & $8.44^{*}$ & 0 & 0 & 0 \\
\hline Jan. & $45.21^{*}$ & 0 & $10,400.00$ & 400.00 & $45.21 *$ & 0 & 0 & 0 \\
\hline
\end{tabular}

Site 1: chlorine-treated final effluent from the wastewater treatment plant.

Site 2: San Francesco Channel mouth.

Site 3: chlorine plus UV-treated final effluent from the wastewater treatment plant.

Site 4: Sant ${ }^{\prime}$ Antonino Channel mouth.

$\mathrm{N} \mathrm{L}^{-1}$ : number of oo/cysts per litre.

*samples containing viable cysts by RT-PCR.

NI: not investigated. 
A semi-nested PCR protocol was performed for amplification of the TPI gene. In the primary PCR reaction, the forward primer AL3544 and the reverse primer AL3545 were used, while the reverse primer TPR1 was used in the second step [26].

For the amplification of 18S-rDNA, the primary PCR was performed using the primers RH11 and RH4 [27]. For the nested PCR, the internal primers Giar-F and Giar-R [28] were used.

All DNA samples were also subjected to a semi-nested PCR to amplify a $400 \mathrm{bp}$ fragment of the N-terminal domain of the gene encoding for the Cryptosporidium spp. outer protein wall (COWP). Two sets of degenerated primers were used; CRY15D and CRY9D in the first step, and CRYINT2D and CRY9D in the second step [29].

All specific Giardia spp. and Cryptosporidium spp. PCR products were purified using a Montage PCR Millipore kit and sequenced using the Dye Deoxy Terminator Cycle Sequencing Kit (Applied Biosystems) on an ABI-PRISM 377 sequencer. Multiple alignment of the nucleotide sequences was performed using Clustal $\mathrm{X}$ and compared with those available in GenBank for Giardia and Cryptosporidium species and genotype identification.

\section{Statistical analysis}

Experimental data obtained from 11 water samples were firstly standardized and then processed using Multiple Regression Analysis (SAS-STAT Software) of Giardia cyst numbers vs. monthly mean temperature and monthly total rainfall (calculated from data collected two days before sampling the day).

\section{Results}

A total of 42 samples (21 from the water channel outlets from wastewater treatment plants and 21 from the water channel inlets into the Lagoon) were produced. Giardia cysts were found by IF in 23 samples from 3 sites (see Table 1). Different cyst concentrations were found throughout the year, with the highest in February and January in the water channel related to the chlorine-treatment plant (Site 2). No cysts were found in the water channel related to the chlorine- plus UVtreatment plant (Site 4). The percentage of positive samples was found to be higher in the effluent from the chlorine-treatment plant (Site 1), followed by the effluent from the chlorine- plus UV-treatment plant (Site 3), and the water channel related to chlorine-treated wastewater where, however, the highest mean cyst NL was detected (Table 2).

As to Cryptosporidium, oocysts were detected by IF in 13 out of 42 samples from all sampling sites; the highest number of oocysts was detected in December and in the water channel - inlet into the Lagoon - related to chlorine-treatment plant (Site 2). Moreover, the highest mean oocyst concentration (Table 1) and the highest percentage of positive samples were here also found (Table 2).

Out of 23 samples positive for Giardia cysts by IF microscopy, 17 were subjected to RT-PCR and viable cysts were detected in 6 samples (Table 1).
The results of multiple regression have shown that only at the inlet of the water channel draining from the chlorine-treatment plant (Site 2) did temperature and rainfall negatively correlate with Giardia cyst numbers $\left(T^{\circ}=-649.44 \pm 153\right.$ and rainfall $\left.=-126.23 \pm 4 ; p=0.01\right)$. At this sampling site, the highest cyst load was found in winter between December and February, when temperatures ranged from $8{ }^{\circ} \mathrm{C}$ to $12{ }^{\circ} \mathrm{C}$. Conversely, in the same water channel, the number of cysts fell from May to October, at temperatures ranging from 19 to $24^{\circ} \mathrm{C}$.

All 23 samples found to be positive to Giardia by IF testing were also PCR-positive, and 20 of them were genotyped by the two different Giardia targets. Assemblages A and B of G. duodenalis were detected; in particular, 15 isolates were identified as Assemblage A and 2 as Assemblage B (Table 2). Incoherent results i.e. belonging to Assemblage A or B depending on the gene target used, were obtained in three samples. Out of eleven samples positive for Cryptosporidium by IF assay, only three were found to be positive by PCR, and sequencing of PCR products allowed the identification of $C$. parvum in only one sample (Table 2).

A total of 47 pools of shellfish haemolymph (23 of R. decussatus and 24 of $M$. galloprovincialis) were collected and analyzed. Both IF and molecular tests gave negative results for Giardia and Cryptosporidium in all pools for both shellfish species.

\section{Discussion}

The results show that waters contaminated by animal and/or human faeces carrying Giardia cysts and Cryptosporidium oocysts are discharged into the Lagoon; Cryptosporidium oocyst concentration was lower in comparison with that of Giardia cysts, whose lowest load occurred in chlorinated plus UV-treated wastewater. Surprisingly, at the inlet where the chlorine-treatment plant discharged into the Lagoon, the number of (oo)cysts was higher than that observed at the channel outlet from the treatment plant. Probably, contamination of this water channel may derive from deliberate illegal runoff of urban origin rather than from livestock farms present in the investigated are. In fact, although these animals have been found to harbour zoonotic species/assemblages in Italy [5], no livestock specific assemblages (i.e. Assemblage E) were identified in association with the zoonotic assemblages in the water channel.

In the chlorine- plus tertiary disk filtration and UV-treatment plant Giardia cyst concentration is very low, and Cryptosporidium is almost absent compared to the chlorine-treatment plant, thus confirming previous data showing that tertiary disk filtration and UV radiation increase the efficacy of chlorine in (oo)cyst removal [30]. The complete absence of cysts and the rare finding of oocysts in the mouth of water channel related to the chlorine- plus tertiary disk filtration and UVtreatment plant can be explained by other factors: this channel is about $4000 \mathrm{~m}$ long from source to mouth, and therefore about three times longer than the other water channel (see Fig. 1). In addition it has a lower water flow than in the other treatment plant, and water draining away into underground water tables may reduce the flow of

Table 2

IF-positive samples, percentages, mean number $\mathrm{L}^{-1}$ and molecular characterization of Giardia cysts and Cryptosporidium oocysts in the sampling sites

\begin{tabular}{|c|c|c|c|c|c|c|}
\hline \multirow{2}{*}{$\begin{array}{l}\text { Sampling } \\
\text { sites }\end{array}$} & \multicolumn{3}{|l|}{ Giardia } & \multicolumn{3}{|l|}{ Cryptosporidium } \\
\hline & IF-positive samples/Tot(\%) & Mean cyst $\mathrm{N} \mathrm{L}^{-1} \pm \mathrm{SD}$ & Assemblage & IF-positive samples/Tot(\%) & Mean oocyst $\mathrm{N} \mathrm{L}^{-1} \pm \mathrm{SD}$ & Genus/species \\
\hline Site 1 & $9 / 11(81.82 \%)$ & $98.8 \pm 150.43$ & A (6) A or B (2)\# & $4 / 11(36.36 \%)$ & $6.99 \pm 10.26$ & Cryptosporidium spp. \\
\hline Site 2 & $7 / 11(63.64 \%)$ & $2853.19 \pm 4645.79$ & $A(5) B(1)$ & $7 / 11(63.64 \%)$ & $584.67 \pm 1745.17$ & Cryptosporidium parvum \\
\hline Site 3 & $7 / 10(70 \%)$ & $37.81 \pm 51.66$ & A (4) B (1) A or B (1)\# & $1 / 10(10 \%)$ & $2.67 \pm 8.43$ & - \\
\hline Site 4 & $0 / 10$ & 0 & - & $1 / 10(10 \%)$ & $10.20 \pm 32.26$ & Cryptosporidium spp. \\
\hline
\end{tabular}

Site 1: chlorine-treated final effluent from the wastewater treatment plant.

Site 2: San Francesco Channel mouth.

Site 3: chlorine plus UV-treated final effluent from the wastewater treatment plant.

Site 4: Sant ${ }^{\prime}$ Antonino Channel mouth.

$\mathrm{N} \mathrm{L}^{-1}$ : number of oo/cysts per litre.

\# incoherent results obtained by using 2 different gene target. 
this water channel, thus exposing (oo)cysts to solar irradiation and high external temperatures above $37^{\circ} \mathrm{C}$ in spring and summer. The possible role of temperature and solar irradiation is also evident in the other water channel (Site 2 ), where from 0 to very low (oo)cyst concentrations were found from May to July. Also, since (oo)cyst recovery efficiency decreases when turbidity of water increases, thus leading to an underestimation of (oo)cyst concentration, this can explain the low concentrations determined at Site 1 when compared to Site 2 .

Different results between IF and molecular methods, already reported for Cryptosporidium in wastewater [31] can be due to the presence of PCR inhibitors in water samples [32]. In this study, although Cryptosporidium oocyst viability was not evaluated, $\beta$-giardin RT-PCR applied to most of IF-positive samples may suggest that viable cysts were discharged into the lagoon and were occasionally found also in UV-treated wastewater. Since this treatment plant uses low pressure lamps - which have twice the germicidal efficacy of medium pressure lamps [33] - interference by turbidity may explain these occasional findings. However, it should be noted that RT-PCR-based methods were found to overestimate cyst [34] or oocyst viability [35].

As regards Giardia molecular typing, isolates mostly belonged to Assemblage $A$, thus confirming previous findings in wastewater and surface water in Italy where the zoonotic Assemblage A is also prevalent in humans and has frequently been isolated in domestic pet animals, farm livestock, and also wild animals [5]. Genotyping of Cryptosporidium isolates allowed us to identify the zoonotic species C. parvum, which was previously found in secondary-treated wastewater in our region [17]. Cryptosporidium is also widespread in Italy and C. parvum is the most frequently detected species $(85.7 \%$ of genotyped isolates) in humans and animals - mainly livestock, but also dogs and shellfish [5]. Therefore, this report further supports the circulation of species/genotypes which are potentially dangerous for human and animal health.

No conclusive remarks can be assigned to the incoherent results, i.e. identification of different Giardia Assemblages obtained in three samples by using two different markers; mechanisms which can explain the occurrence of mixed templates as (i) "true" mixed infection and (ii) allelic sequence herozygosity still remain under evaluation and further studies are needed to better explain these findings, as previously suggested [36-38].

Giardia and Cryptosporidium have been detected in several species of edible shellfish [11-16] in Europe, including Italy [39-41]. However, in the context studied here, both IF and PCR assays showed that the shellfish were unaffected. Since the method used for (oo)cyst recovery from shellfish was previously reported to have a high efficiency [24,25], several factors may contribute to this absence: a) the cysts found in water were not always viable and can be fully destroyed before reaching the shellfish farms; b) the concentration of (oo)cysts is diluted because of the width of the Lagoon and the underground circulation of several freshwater streams, which are documented in its south-eastern area [42]; c) sea water flows into the lagoon in the northern isthmus (Foce Capoiale) and flows out through the southern isthmus (Foce Varano) (Fig. 1), so that the water is often replaced and cleaned by the constant presence of circular currents and tides. Other factors such as chemical (i.e. ammonia, $\mathrm{pH}$ and salinity) and physical (i.e. temperature and solar radiation) parameters were reported to influence the (oo)cyst concentration in the environment [33]. It should be noted that in summer - and more recently also in spring - the surface water temperature reaches $32{ }^{\circ} \mathrm{C}$ in the area studied. Considering that shellfish are harvested in water between $50 \mathrm{~cm}$ and $2 \mathrm{~m}$ deep, direct sunlight may negatively influence the survival of protozoa. It has also been demonstrated that Giardia cysts - numerically prevalent in this study - are in general less stable in water than Cryptosporidium [33].

The European Community Regulations (Nos 853 and 854) which are currently in force in Italy provide for official surveillance to control the water quality for shellfish farming (number of coliforms, Escherichia coli, metals, etc). On the basis of these quality parameters, sea or freshwater are classified as Class A (in which shellfish are E. coli free and can be marketed without depuration processes), Class B, (in which shellfish - with no more than $4600 \mathrm{E}$. coli/100 g of tissue - can be marketed without depuration) and Class C (where shellfish - with no more than 46,000 E. coli/100 g of tissue - must be transferred to Class B water for depuration). The Varano Lagoon is classified as Class A water by the Regional Agency for Water Control (ARPA) on the basis of these quality parameters. In the light of our results it is reasonable to confirm the Varano Lagoon as Class A water for shellfish farming.

This is the first study dealing with a simultaneous investigation into the presence of Giardia and Cryptosporidium - in water intakes and in harvested shellfish - in a geographically closed environment. In this respect, the Varano Lagoon may be a good model of study for evaluating the ecological health status of lagoons. The environmental ecology of the Varano Lagoon can certainly change year to year, and for this reason public health institutions must remain vigilant, constantly monitoring the sanitary conditions of the Lagoon. Besides monitoring chemical and physical parameters and the circulation currents existing in this closed environment, it is also important to screen the water flowing into the lagoon - in particular the wastewater (i.e. urban and/or livestock runoff), which may be illegally discharged - and also to survey harvested shellfish whose role as bioindicators of water contamination is accepted and confirmed worldwide $[43,41]$. The combination of both IF and molecular tests on water and shellfish haemolymph can guarantee a reliable method for screening purposes [44,41], and sequencing analysis can provide information about the zoonotic and/or anthroponotic source of contamination. Moreover, these data may be useful considering that bathing is allowed along the Varano Lagoon coast and also that water channels receiving treated wastewater are commonly used for agricultural purposes, i.e. irrigation of fruit trees and vegetables, while untreated wastewater may be used illegally for the same purposes in this geographical area. Lastly, it is important not to neglect frequent routine monitoring of wastewater treatment performance, as well as the promotion of advanced inactivation technology in the wastewater treatment plants.

\section{Acknowledgments}

This work was supported by a research grant for Research of Relevant National Interest (PRIN 2005-2007) from the Ministry of the University and Research, Italy.

The authors are grateful to Marco Lalle of the Istituto Superiore di Sanità (Rome, Italy) for kindly providing the culture of trophozoites (WB $\mathrm{C}_{6}$ strain).

The authors are also grateful to Dr. Biancamaria Cudillo of the Agenzia Regionale Prevenzione e Ambiente (Foggia, Italy) for her outstanding technical support.

\section{References}

[1] Thompson RC. The zoonotic significance and molecular epidemiology of Giardia and giardiasis. 2004;126:15-35.

[2] Hunter PR, Thompson RC. The zoonotic transmission of Giardia and Cryptosporidium. Int J Vet Parasitol 2005;35:1181-90.

[3] Xiao L, Ryan UM. Cryptosporidiosis: an update in molecular biology. Curr Opin Infect Dis 2004; 17:483-90.

[4] Cacciò SM, Thompson RC, McLauchlin J, Smith HV. Unravelling Cryptosporidium and Giardia epidemiology. Trends Parasitol 2005;21:430-7.

[5] Giangaspero A, Berrilli F, Brandonisio O. Giardia and Cryptosporidium and public health: the epidemiological scenario from the Italian perspective. Parasitol Res 2007; 101:1169-82.

[6] Thurston-Enriquez JA, Watt P, Dowd SE, Enriquez R, Pepper IL, Gerba CP. Detection of protozoan parasites and microsporidia in irrigation waters used for crop production. J Food Prot 2002;65:378-82.

[7] Fayer R, Dubey JP, Lindsay DS. Zoonotic protozoa: from land to sea. Trends Parasitol 2004;20:531-6.

[8] Fayer R, Graczyk TK, Lewis EJ, Trout JM, Farley CA. Survival of infectious Cryptosporidium parvum oocysts in seawater and eastern oysters (Crassostrea virginica) in the Chesapeake Bay. Appl Environ Microbiol 1998;64:1070-4. 
[9] Fayer R, Trout JM, Lewis EJ, Santin M, Zhou L, Lal AA, et al. Contamination of Atlantic coast commercial shellfish with Cryptosporidium. Parasitol Res 2000;89:141-5.

[10] Graczyk TK, Farley CA, Fayer R, Lewis EJ, Trout JM. Detection of Cryptosporidium oocysts and Giardia cysts in the tissues of eastern oysters (Crassostrea virginica) carrying principal oyster infectious diseases. J Parasitol 1998;84:1039-42.

[11] Azevedo C. Fine structure of Perkinsus atlanticus n. sp. (Apicomplexa, Perkinsea) parasite of the clam Ruditapes decussatus from Portugal. J Parasitol 1989;75:627-35.

[12] Chalmers RM, Sturdee AP, Mellors P, Nicholson V, Lawlor F, Kenny F, et al. Cryp tosporidium parvum in environmental samples in the Sligo area, Republic of Ireland: a preliminary report. Lett Appl Microbiol 1997;25:380-4.

[13] Freire-Santos F, Oteiza-Lopez AM, Vergara-Castiblanco CA, Ares-Mazas E, AlavarezSuarez E, Garcia-Martin O. Detection of Cryptosporidium oocysts in bivalve molluscs destined for human consumption. J Parasitol 2000;86:853-4.

[14] Gomez-Bautista M, Ortega-Mora LM, Tabares E, Lopez-Rodas V, Costas E. Detection of infectious Cryptosporidium parvum oocysts in mussels (Mytilus galloprovincialis) and cockles (Cerastoderma edule). Appl Environ Microbiol 2000;66:1866-70.

[15] Gomez-Couso H, Freire-Santos F, Martinez-Urtaza J, Garcia-Martin O, Ares-Mazas ME. Contamination of bivalve molluscs by Cryptosporidium oocysts: the need for new quality control standards. Int J Food Microbiol 2003;87:97-105.

[16] Graczyk TK, Conn DB, Lucy F, Minchin D, Tamang L, Moura LN, et al. Human waterborne parasites in zebra mussels (Dreissena polymorpha) from the Shannon River drainage area, Ireland. Parasitol Res 2004;93:385-91.

[17] Lonigro A, Pollice A, Spinelli R, Berrilli F, Di Cave D, D'Orazi C, et al. Giardia cysts and Cryptosporidium oocysts in membrane-filtered municipal wastewater used for irrigation. Appl Environ Microbiol 2006;72:7916-8.

[18] USEPA. Cryptosporidium and Giardia in Water by Filtration/IMS/FA. Cincinnati, OH United States Environmental Protection Agency; April 2001. EPA-821-R-01-025.

[19] Kaucner C, Stinear T. Sensitive and rapid detection of viable Giardia cysts and Cryptosporidium parvum oocysts in large-volume water samples with wound fiberglass cartridge filters and reverse transcription-PCR. Appl Environ Microbiol 1998;64:1743-9.

[20] Mahbubani MH, Bej AK, Perlin MH, Schaefer 3rd FW, Jakubowski W, Atlas RM. Differentiation of Giardia duodenalis from other Giardia spp. by using polymerase chain reaction and gene probes. J Clin Microbiol 1992;30:74-8.

[21] Keister DB. Axenic culture of Giardia lamblia in TYI-S-33 medium supplemented with bile. Trans R Soc Trop Med Hyg 1983;77:487-8.

[22] Gillin FD, Boucher SE, Rossi SS, Reiner DS. Giardia lamblia: the roles of bile, lactic acid, and $\mathrm{pH}$ in the completion of the life cycle in vitro. Exp Parasitol 1989;69:164-74.

[23] Thrusfield M. Surveys. In Veterinary Epidemiology. Oxford, UK: Blackwell Science; 2006.

[24] Graczyk TK, Fayer R, Lewis EJ, Trout JM, Farley CA. Cryptosporidium oocysts in Bent mussels (Ischadium recurvum) in the Chesapeake Bay. Parasitol Res 1999;85:518-21.

[25] Graczyk TK, Marcogliese DJ, de Lafontaine Y, Da Silva AJ, Mhangami-Ruwende B, Pieniazek NJ. Cryptosporidium parvum oocysts in zebra mussels (Dreissena polymorpha): evidence from St. Lawrence River. Parasitol Res 2001;87:231-4.

[26] Sulaiman IM, Fayer R, Bern C, Gilman RH, Trout JM, Schantz PM, et al. Triosephosphate isomerase gene characterization and potential zoonotic transmission of Giardia duodenalis. Emerg Infect Dis 2003;9:1444-52.
[27] Hopkins RM, Meloni BP, Groth DM, Wetherall JD, Reynoldson JA, Thompson RC. Ribosomal RNA sequencing reveals differences between the genotypes of Giardia isolates recovered from humans and dogs living in the same locality. J Parasitol 1997;83:44-51.

[28] Read C, Walters J, Robertson ID, Thompson RC. Correlation between genotype of Giardia duodenalis and diarrhoea. Int J Parasitol 2002;32:229-31.

[29] Traversa D, Iorio R, Otranto D, Modry' D, Šlapeta J. Cryptosporidium from tortoises: genetic characterisation, phylogeny and zoonotic implications. Mol Cell Probes 2008;22:122-8.

[30] Betancourt WQ, Rose JB. Drinking water treatment processes for removal of Cryptosporidium and Giardia. Vet Parasitol 2004;126:219-34

[31] Cacciò SM, De Giacomo M, Aulicino FA, Pozio E. Giardia cysts in wastewater treatment plants in Italy. Appl Environ Microbiol 2003;69:3393-408.

[32] Smith HV, Cacciò SM, Tait A, McLauchlin J, Thompson RC. Tools for investigating the environmental transmission of Cryptosporidium and Giardia infections in humans. Trends Parasitol 2006;22:160-7.

[33] Erickson MC, Ortega YR. Inactivation of protozoan parasites in food, water, and environmental systems. J Food Prot 2006;69:2786-808.

[34] Mahbubani MH, Bej AK, Perlin M, Schaefer III FW, Jakubowski W, Atlas RM. Detection of Giardia cysts by using the polymerase chain reaction and distinguishing live from dead cysts. Appl Environ Microbiol 1991;57:3456-61.

[35] Robertson LJ, Gjerde BK. Cryptosporidium oocysts: challenging adversaries? Trends Parasitol 2007;23:344-7.

[36] Wielinga CM, Thompson RC. Comparative evaluation of Giardia duodenalis sequence data. Parasitology 2007;134:1795-821.

[37] Gelanew T, Lalle M, Hailu A, Pozio E, Cacciò SM. Molecular characterization of human isolates of Giardia duodenalis from Ethiopia. Acta Trop 2007;102:92-9.

[38] Cacciò SM, Ryan U. Molecular epidemiology of giardiasis. Mol Biochem Parasitol 2008;160:75-80

[39] Molini U, Iorio R, Traversa D, Paoletti B, Giansante C, Giangaspero A. Rilievo di Giardia spp. e Cryptosporidium spp. nelle vongole (Chamelea gallina) della costa abruzzese. Ittiopatologia 2004;1:34-40.

[40] Giangaspero A, Molini U, Iorio R, Traversa D, Paoletti B, Giansante C. Cryptosporidium parvum oocysts in seawater clams (Chamelea gallina) in Italy. Prev Vet Med 2005;69:203-12.

[41] Molini U, Traversa D, Ceschia G, Iorio R, Boffo L, Zentilin A et al Temporal occurrence of Cryptosporidium in the Asian clam Ruditapes philippinarum in the Northern Adriatic Italian Lagoons. J Food Prot 2007;70:494-9.

[42] Spagnoli F, Specchiulli A, Scirocco T, Carapella G, Villani P, Casolino G, et al. The Varano Lagoon: hydrologic characteristics and sediment composition. Ecology 2002;23:384-94.

[43] Graczyk TK, Conn DB, Marcogliese DJ, Graczyk H, De Lafontaine Y. Accumulation of human waterborne parasites by zebra mussels (Dreissena polymorpha) and Asian freshwater clams (Corbicula fluminea). Parasitol Res 2003;89:107-12.

[44] Gomez-Couso H, Mendez-Hermida F, Ares-Mazas ME. Levels of detection of Cryptosporidium oocysts in mussels (Mytilus galloprovincialis) by IFA and PCR methods. Vet Parasitol 2006;141:60-5. 